\title{
6. LATE APTIAN AND CENOMANIAN-TURONIAN PLANKTONIC FORAMINIFERS FROM DEEP SEA DRILLING PROJECT SITE 585, LEG 89, EAST MARIANA BASIN ${ }^{1}$
}

\author{
I. Premoli Silva, Dipartimento di Scienze della Terra, Universitá di Milano \\ and \\ William V. Sliter, U.S. Geological Survey, Menlo Park, California ${ }^{2}$
}

\begin{abstract}
Planktonic foraminifers from the late Aptian and the Cenomanian-Turonian of Site 585, East Mariana Basin, provide new age data for western Pacific geologic events. The Aptian assemblage dates the volcaniclastic sequence from the bottom of Site 585 and includes several species newly reported from the Pacific Ocean. The Cenomanian-Turonian assemblage constrains the organic-carbon-rich anoxic strata recorded at Site 585 to the Cenomanian-Turonian oceanic anoxic event. Sporadic occurrences of mostly rare, poorly preserved planktonic foraminifers record pulses of sedimentation during the Aptian-Albian, Cenomanian-Turonian, Coniacian-Santonian, and Campanian-Maestrichtian that transported and reworked the pelagic sediments downslope to abyssal depositional environments.
\end{abstract}

\section{INTRODUCTION}

Cretaceous sediments recovered from Site 585 in the East Mariana Basin (Fig. 1) at a water depth of $6109 \mathrm{~m}$ contain sporadic occurrences of often poorly preserved, sparse planktonic foraminifers that range in age from Aptian to Maestrichtian. Two single-bit holes at Site 585 penetrated an 892.8-m sequence of nannofossil chalk, turbiditic claystone, radiolarian claystone, clayey limestone, chert, and volcaniclastic sandstone before terminating in upper Aptian sediments. Grading is apparent throughout the sequence from the coarse volcaniclastic sandstone and breccia in the basal Aptian to Albian section to the nannofossil claystone in the upper Campanian and Maestrichtian section.

Planktonic foraminifers recovered from this sequence are considered redeposited from nearby paleotopographic highs because (1) the often size-sorted assemblages are included in clearly redeposited, turbiditic layers, and (2) the Mariana Basin was located well below the carbonate compensation depth (CCD) since the Early Cretaceous according to the inferred age of the crust at Site 585 . Autochthonous abyssal benthic foraminifers found associated with the pelagic assemblage that consists of planktonic foraminifers, reworked calcareous nannofossils, and size-sorted radiolarians throughout the Cretaceous sequence (Sliter, this volume) corroborate the interpretation of downslope transport for the pelagic material.

The sporadic occurrence of Cretaceous pelagic organisms at Site 585 reflects the episodic pulses of resedimentation resulting from volcanism, sea-level changes, and plate motion (Sliter, this volume). Erosion of volcanic edifices that had been built to sea level by Aptian time contributed to the influx of Aptian and Albian

\footnotetext{
${ }^{1}$ Moberly, R., Schlanger, S. O., et al., Init. Repts. DSDP, 89: Washington (U.S. Govt. Printing Office)

2 Addresses: (Premoli Silva) Dipartimento di Scienze della Terra, Universitá di Milano, Via Mangiagalli, 34, Milan, 20133 Italy; (Sliter) U.S. Geological Survey, Menlo Park, CA 94205.
}



Figure 1. Location of Site 585 drilled in the East Mariana Basin and the other sites drilled during Leg 89 . (Contours in fathoms.)

planktonic foraminifers from Cores 585-54 to 585-36 in Hole 585 and Cores $585 \mathrm{~A}-18$ to $585 \mathrm{~A}-11$ in Hole $585 \mathrm{~A}$. Changes in sea level appear to be more directly related to resedimentation during the Cenomanian-Turonian and the Coniacian-Santonian parts of Site 585 (Cores 585-32 to 585-29 and Core 585A-9). The Campanian and Maestrichtian pulse of resedimentation apparently is related to renewed midplate volcanism that uplifted nearby seamounts. Planktonic foraminifers that record this pulse were found in Cores 585-23 to 585-20 and Cores 585A-5 to $585 \mathrm{~A}-3$ (see Site 585 report, this volume).

Here we briefly describe and illustrate planktonic foraminifers from two biostratigraphic intervals that yield- 
ed moderately abundant assemblages with fewer reworked specimens; the late Aptian, and the CenomanianTuronian. These faunas are important as they (1) are newly, or previously were rarely, recorded from the $\mathrm{Pa}$ cific Ocean, (2) date the volcaniclastic sequence from the bottom of Hole $585 \mathrm{~A}$ and thus provide a means to estimate the initiation of volcanism in this portion of the Pacific, and (3) constrain the age of the organic-carbon-rich anoxic layer that corresponds to the Cenomanian-Turonian oceanic anoxic event of Schlanger and Jenkyns (1976) (see Schlanger and Moberly; this volume). Additional samples with planktonic foraminifers from both Holes 585 and 585A are listed in Table 1. These samples, however, contained poorly preserved and often rare, size-sorted specimens. The more abundant assemblages consist primarily of reworked or long-ranging forms (see Site 585 report, this volume).

\section{FORAMINIFERAL ZONATION}

The zonal scheme used in this study and the important biostratigraphic events are shown in Figure 2. The zonation is a composite of those of Longoria (1974), Sigal (1977), Robaszynski and Caron (1979), and Premoli Silva and Sliter (1981). The geologic time scale used on Leg 89 is that of van Hinte (1976).

\section{LATE APTIAN ASSEMBLAGES}

Rare age-diagnostic planktonic foraminifers were recovered from Hole 585A (Fig. 3). Sample 585A-18-2, 90-93 cm yielded only two specimens of Hedbergella trocoidea. A somewhat more abundant, moderately preserved assemblage in Sample 585A-16,CC (22-24 cm) included $H$. trocoidea in addition to Globigerinelloides ferreolensis and Ticinella bejaouaensis. Although rework-

Table 1. Additional samples with rare to common, poorly preserved planktonic foraminifers from Holes 585 and $585 \mathrm{~A}$.

\begin{tabular}{|c|c|c|c|}
\hline \multicolumn{2}{|c|}{ Hole 585} & \multicolumn{2}{|c|}{ Hole $585 \mathrm{~A}$} \\
\hline $\begin{array}{c}\text { Sample } \\
\text { (core-section, } \\
\text { interval in } \mathrm{cm} \text { ) }\end{array}$ & Abundance & $\begin{array}{c}\text { Sample } \\
\text { (core-section, } \\
\text { interval in } \mathrm{cm} \text { ) }\end{array}$ & Abundance \\
\hline $18-1,76-79$ & C, reworked & $3-1,73-75$ & VR, reworked \\
\hline $18-2,23-27$ & $\mathrm{~F}$, reworked & $3-1,128-130$ & C, reworked \\
\hline $20-1,0-1$ & VR & $3-2,32-34$ & $\mathrm{R}$ \\
\hline $20-1,17-19$ & C & $5, \mathrm{CC}$ & $\mathrm{R}$, reworked \\
\hline $20-2,8-10$ & $\mathrm{~F}$ & $11-5,43-45$ & $\mathrm{R}$ \\
\hline $20-3,52-53$ & C & & \\
\hline $20-3,108-109$ & $\mathrm{~F}$ & & \\
\hline $20-3,146-148$ & $\mathrm{R}$ & & \\
\hline $23, \mathrm{CC}$ & $\mathbf{R}$ & & \\
\hline $29-2,46-48$ & $\mathrm{~F}$, reworked & & \\
\hline $30-1,4-6$ & $\mathrm{~F}$, reworked & & \\
\hline $32-2,116-118$ & $\mathrm{~F}$, reworked & & \\
\hline $36-1,31-33$ & $\mathrm{R}$ & & \\
\hline $39-2,16-17$ & VR & & \\
\hline $41, \mathrm{CC}$ & 1 specimen & & \\
\hline $42, \mathrm{CC}(13-15)$ & VR & & \\
\hline $44, \mathrm{CC}$ & VR & & \\
\hline $49-3,8-10$ & VR & & \\
\hline $49-6,53-55$ & VR & & \\
\hline $51-3,54-56$ & VR & & \\
\hline $52-1,118-119$ & VR & & \\
\hline $54-3,26-28$ & 1 specimen & & \\
\hline
\end{tabular}

Note: $\mathrm{C}=$ common; $\mathrm{F}=$ few; $\mathrm{R}=$ rare; and $\mathrm{VR}=$ very rare. ing cannot be ruled out, the co-occurrence of the above species suggests that the fauna belongs to the lower part of the Ticinella bejaouaensis Zone, and is thus of latest Aptian age. This age assignment is in agreement with that inferred from calcareous nannofossils and benthic foraminifers (Bergen, and Sliter, respectively, this volume).

\section{CENOMANIAN-TURONIAN ASSEMBLAGES}

As shown in Figure 3, five samples (two from Hole 585 and three from Hole 585A) yielded a more diversified, moderately well preserved planktonic fauna. All five assemblages clearly are reworked, as demonstrated by the occurrence of several specimens of Rotalipora brotzeni, $R$. greenhornensis, and rare $R$. cushmani of Cenomanian age, associated with Dicarinella hagni, Whiteinella aprica, and Heterohelix reussi. The latter species are known to appear after the extinction of the former taxa and within the Whiteinella archaeocretacea Zone that straddles the Cenomanian/Turonian boundary (see Robaszynski and Caron, 1979). All the assemblages are dominated by representatives of the genus Whiteinella. Beside $W$. aprica, the species $W$. baltica, $W$. brittonensis, and $W$. sp. cf. $W$. archaeocretacea were also identified.

Species generally associated with the $W$. archaeocretacea Zone such as Dicarinella imbricata, D. canaliculata, and Praeglobotruncana praehelvetica were not found, nor were true Whiteinella archaeocretacea. Moreover, Praeglobotruncana helvetica and marginotruncanids are also missing. On the basis of the species identified, all five assemblages are attributed to the Whiteinella archaeocretacea Zone and dated to the Cenomanian/Turonian boundary.

Two discrete organic-carbon-rich layers are recorded at Site 585 in Samples 585-32-3, 79-82 cm and 585A$8, \mathrm{CC}$. In Hole 585 , the dark, organic-carbon-rich layer lies within the Whiteinella archaeocretacea Zone, and can be dated at the Cenomanian/Turonian boundary. In Hole 585A all the planktonic foraminiferal faunas were recovered from layers below the dark, organic-carbonrich level, and no similar planktonic foraminiferal assemblages were found in the overlying part. The similarity with the planktonic faunas recovered from Hole 585 would suggest that the dark, organic-carbon-rich layer occupies a similar position in both holes. It appears that both layers are related to the same episode of anoxia, and that they are coeval. Although the possibility of reworking in younger layers cannot be ruled out, the organic-carbon-rich layer seems to correspond to the Cenomanian-Turonian oceanic anoxic event, dated at the Cenomanian/Turonian boundary by Schlanger and Jenkyns (1976).

\section{TAXONOMIC NOTES}

Species of Whiteinella positively identified from Site 585 include $W$. aprica, $W$. baltica, and $W$. brittonensis. Morphologic variation, however, was noted in specimens attributed to or somewhat resembling $W$. archaeocretacea. Some specimens display a low spire, typical of $W$. archaeocretacea with five and one half chambers in the last whorl but without the typical compressed ultimate chamber. These specimens are attributed to $W$. sp. cf. 


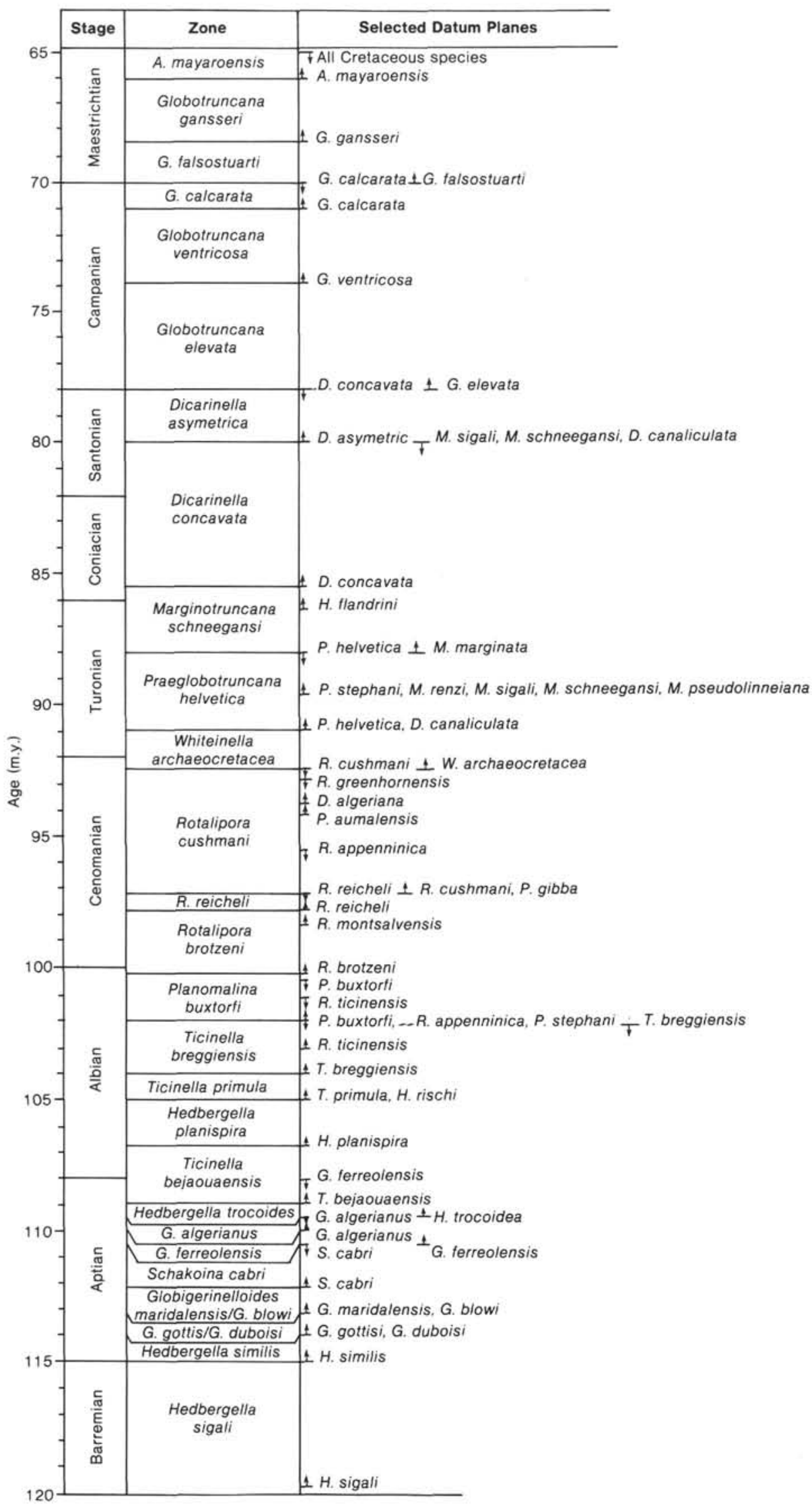

Figure 2. Cretaceous planktonic foraminifer zones and selected datum levels. Zonal scheme after Longoria (1974), Sigal (1977), Robaszynski and Caron (1979), and Premoli Silva and Sliter (1981). Geologic time scale after van Hinte (1976). Arrows show first and last occurrences. 


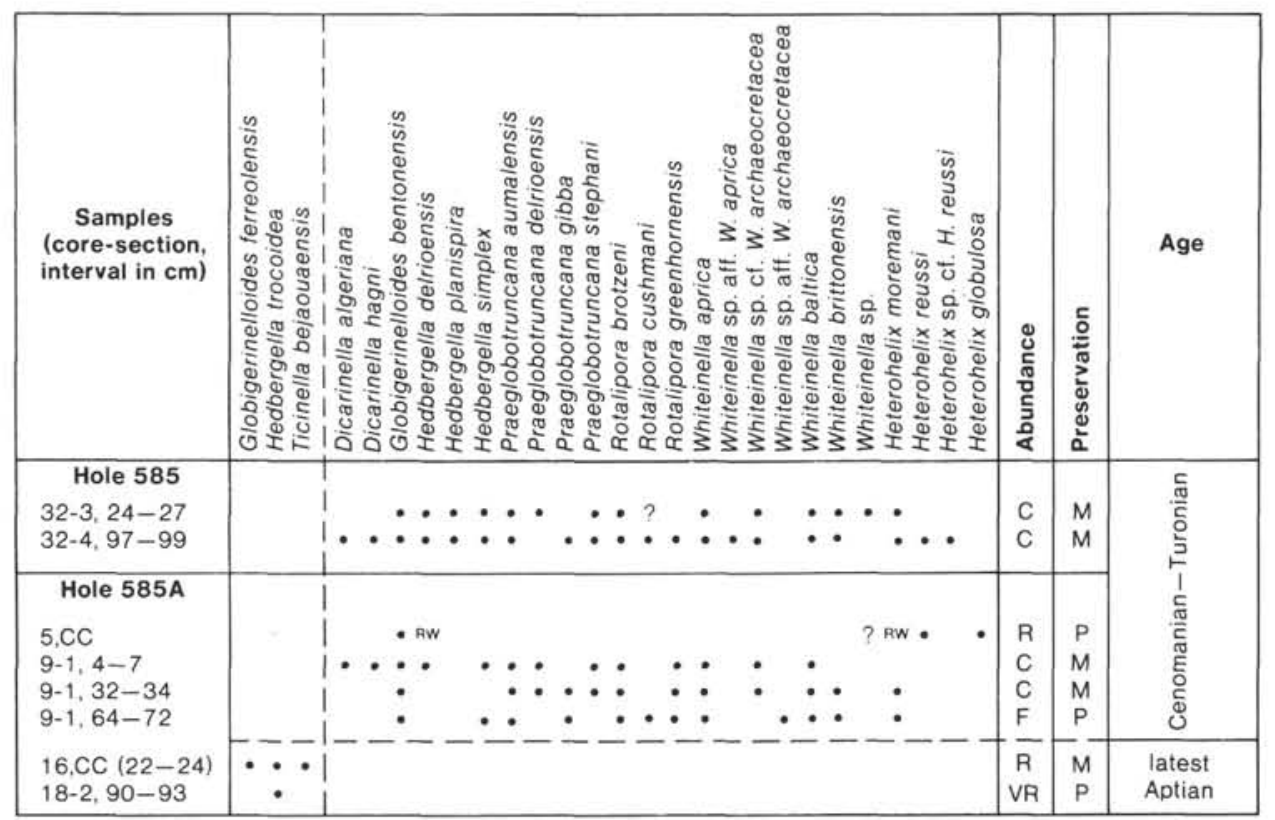

Figure 3. Distribution of latest Aptian and Cenomanian-Turonian planktonic foraminifers in Hole 585A and Cenomanian-Turonian planktonic foraminifers in Hole 585, Leg 89, East Mariana Basin. (Symbols: Samples $-\mathrm{RW}=$ reworked. Abundance $-\mathrm{C}=$ common; $\mathrm{F}=$ few; $\mathrm{R}=$ rare; $\mathrm{VR}=$ very rare. Preservation $-\mathrm{M}=$ moderate; $\mathrm{P}=$ poor; ? = questionable identification.)

W. archaeocretacea (Plates 7-8). Other closely related specimens with a low spire but with a more extended final whorl consisting of six chambers are identified as $W$. sp. aff. W. archaeocretacea (Plate 6). Occasional specimens were found with a higher dorsal spire and a more extended final whorl associated with a compressed ultimate chamber-in other words, a spire typical of W. apri$c a$ associated with the ultimate chamber morphology typical of $W$. archaeocretacea. These forms are referred to $W$. sp. aff. W. aprica (Plate 8). Finally, the several specimens referred to $W$. baltica, if correctly identified, seem to belong to the extreme range of the species with five chambers in the final whorl. These specimens lacked surface ornamentation similar to incipient costellae and thus were not referred to the primitive rugoglobigerines.

\section{ACKNOWLEDGMENTS}

The authors are indebted to DSDP for having been invited to participate on board the Glomar Challenger during Leg 89 . We also thank
Agostino Rizzi, Centro Studi per la Stratigrafia e Petrografia della Alpi Centrali, CNR, Milano, for the scanning electron micrographs, and Michele Caron for comments regarding taxonomic aspects of this study. The study was supported by the MPI $40 \%$ grant to I.P.S.

\section{REFERENCES}

Longoria, J. F., 1974. Stratigraphic, morphologic, and taxonomic studies of Aptian planktonic Foraminifera. Rev. Espanola Micropaleontol., (No. extra Diciembre 1974), 1-134.

Premoli Silva, I. and Sliter, W. V., 1981. Cretaceous planktonic foraminifers from the Nauru Basin, Leg 61, Site 462, western equatorial Pacific. In Larson, R. L., Schlanger, S. O., et al., Init. Repts. DSDP, 61: Washington (U.S. Govt. Printing Office), 423-437.

Robaszynski, F., and Caron, M. (Eds.), 1979. Atlas des foraminiferes planctoniques du cretace moyen (mer boreale et tethys). Cahiers de Micropaleontologie (2 vols.).

Schlanger, S. O., and Jenkyns, H. C., 1976, Cretaceous oceanic anoxic sediments: causes and consequences. Geol. Mijnbouw, 55:179184.

Sigal, J., 1977. Essai de zonation du Cretace mediterraneen a l'aide des foraminiferes planctoniques. Geol. Mediterr., 4:99-108.

van Hinte, J. E., 1976. A Cretaceous time scale. Bull. Am. Assoc. Pet. Geol., 60:498-516. 


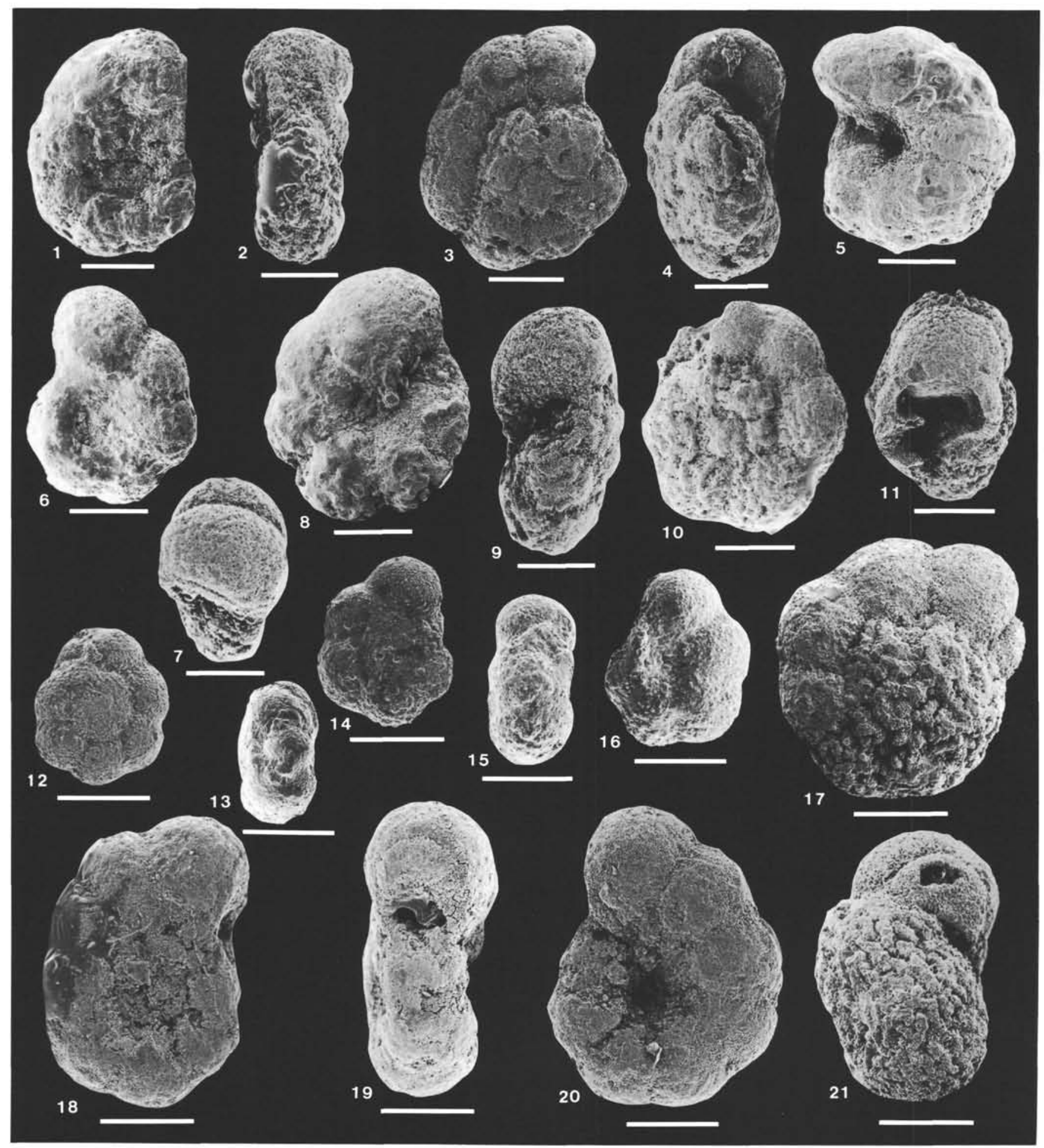

Plate 1. Scale bar $=100 \mu \mathrm{m} . \quad 1-2$. Globigerinelloides ferreolensis (Moullade), Sample 585A-16,CC (22-24 cm), (1) spiral view, (2) side view. 35. Ticinella bejaouaensis Sigal, Sample $585 \mathrm{~A}-16, \mathrm{CC}(22-24 \mathrm{~cm}),(3)$ spiral view, (4) side view, (5) umbilical view. 6-7. Globigerinelloides ferreolensis (Moullade), Sample 585A-16,CC (22-24 cm), (6) spiral view, (7) view of last chamber. 8-9. Hedbergella trocoidea (Gandolfi), Sample 585A-16,CC (22-24 cm), (8) umbilical view, (9) side view. 10-11. Hedbergella trocoidea (Gandolfi), Sample 585A-16,CC (22-24 cm), (10) spiral view, (11) detail of the wall. 12-13. Hedbergella trocoidea (Gandolfi), Sample 585A-18-2, 90-93 cm, (12) spiral view (13) side view. 14-16. Hedbergella trocoidea (Gandolfi), Sample 585A-18-2, 90-93 cm, (14) spiral view, (15) side view, (16) umbilical view. 17, 21. Hedbergella trocoidea (Gandolfi), Sample 585A-16,CC (22-24 cm), (17) spiral view, (21) side view. 18-20. Ticinella bejaouaensis Sigal, Sample 585A-16,CC (22$24 \mathrm{~cm}$ ), (18) sprial view (corroded), (19) side view, (20) umbilical view. 


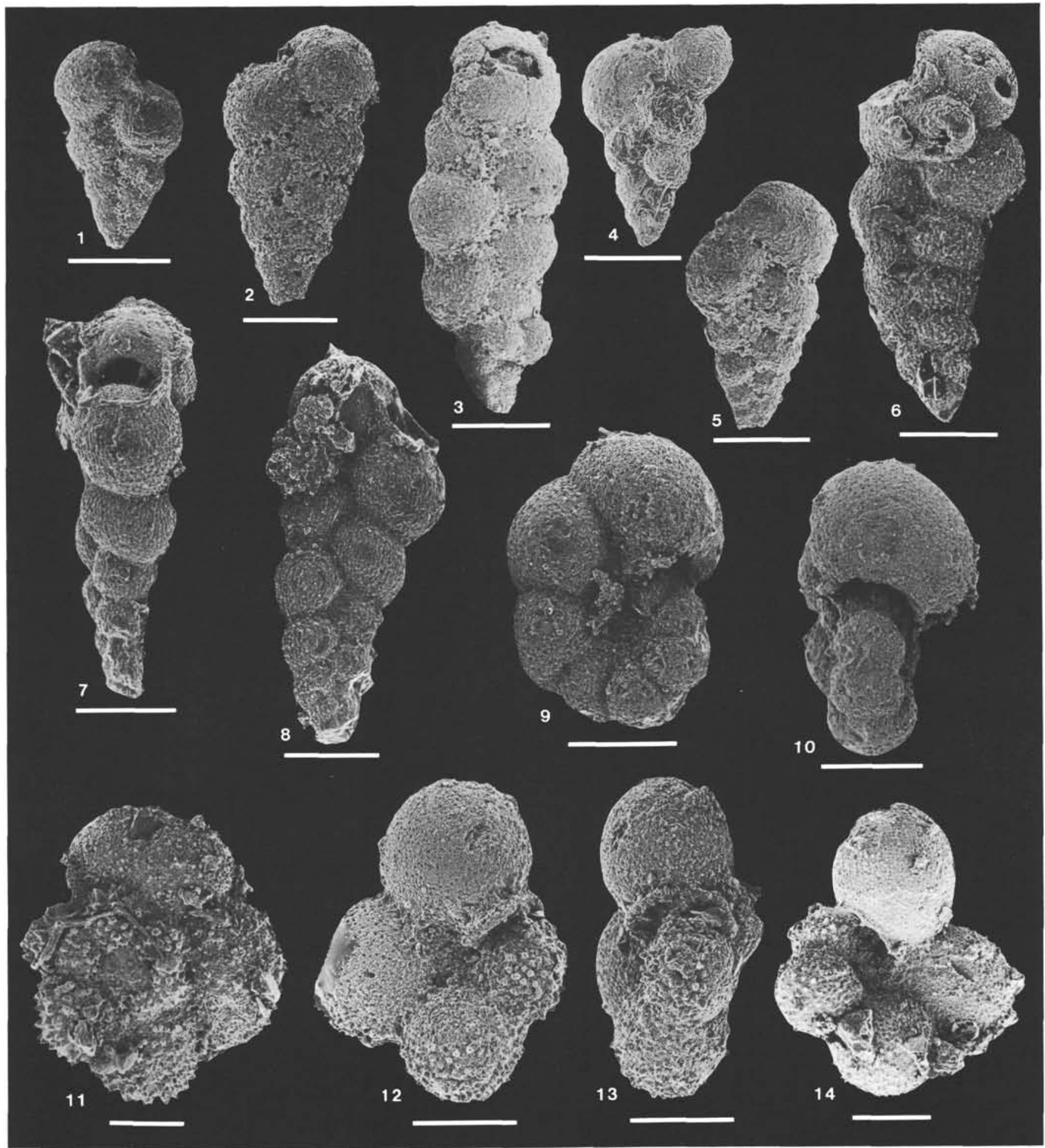

Plate 2. Scale bar $=100 \mu \mathrm{m}$. 1. Heterohelix globulosa (Ehrenberg), Sample 558A-5,CC. 2. Heterohelix moremani (Cushman), Sample 585A-9-1, 32-34 cm. 3. Heterohelix moremani (Cushman), Sample 585A-9-1, 32-34 cm, gerontic specimen similar to the holotype. 4-5. Heterohelix moremani (Cushman), Sample 585A-9-1, 32-34 cm. 6. Heterohelix sp. cf. H. reussi (Cushman), Sample 585-32-4, 97-99 cm. 7-8. Heterohelix reussi (Cushman), Sample 585-32-4, 97-99 cm, (7) front view, (8) side view. 9-10. Globigerinelloides bentonesis (Morrow), Sample 585-32-4, 97-99 cm, (9) spiral view, (10) side view. 11. Hedbergella delrioensis (Carsey), Sample 585-32-4, 97-99 cm, spiral view. 12-13. Hedbergella simplex (Morrow), Sample 585A-9-1, 4-7 cm, (12) umbilical view, (13) side view. 14. Hedbergella simplex (Morrow), Sample 585-32-4, 97-99 cm, umbilical view. 


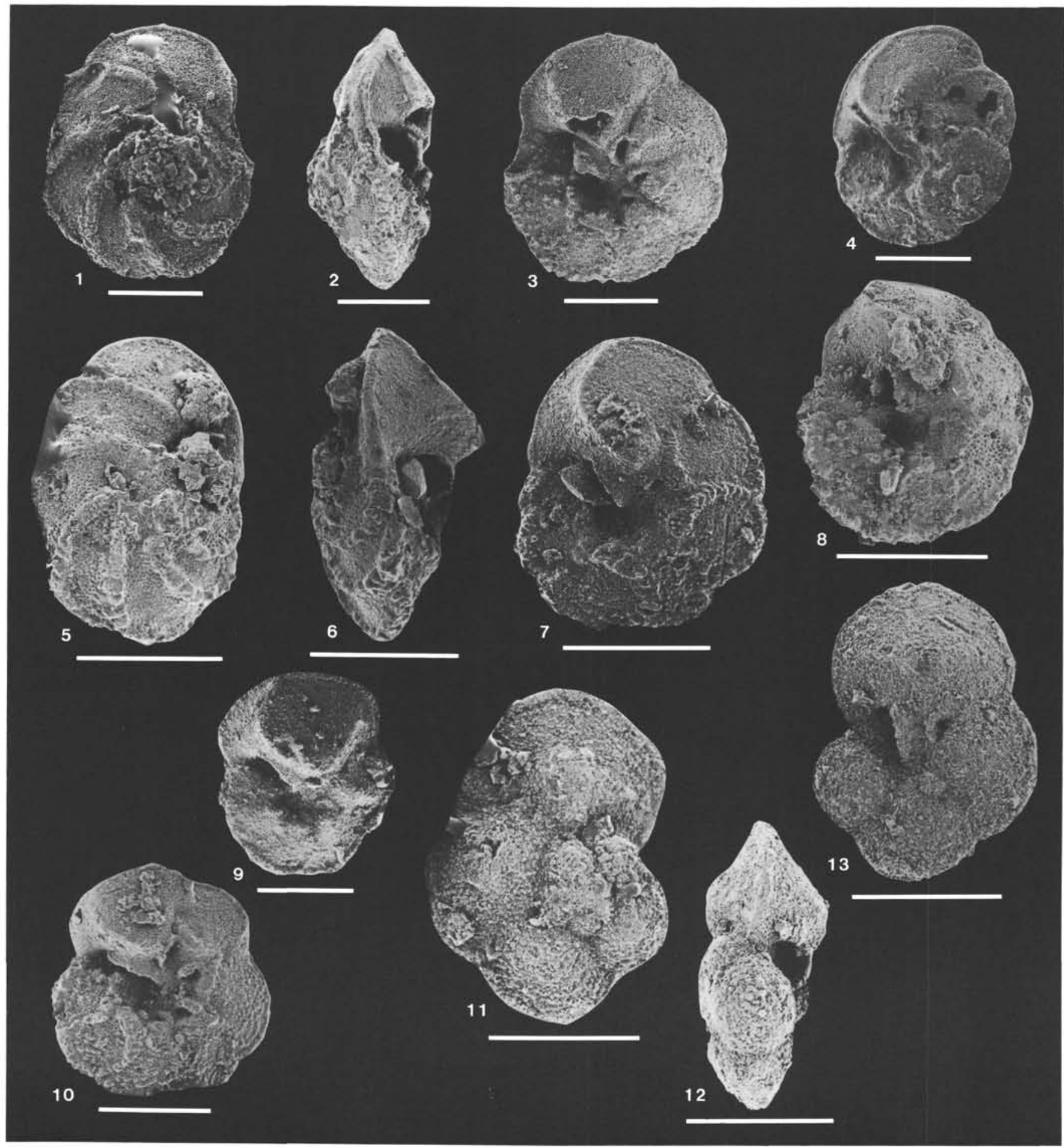

Plate 3. Scale bar $=200 \mu \mathrm{m}$. 1-3. Rotalipora greenhornensis (Morrow), Sample 585-32-4, 97-99 cm, (1) spiral view, (2) side view, (3) umbilical view. 4. Rotalipora brotzeni (Sigal), Sample 585-32-4, 97-99 cm, umbilical view. 5-7. Rotalipora brotzeni (Sigal), Sample 585-32-4, 97-99 $\mathrm{cm}$, (5) spiral view, (6) side view, (7) umbilical view. 8. Rotalipora greenhornensis (Morrow), Sample 585-32-4, 97-99 cm, umbilical view. 9. Rotalipora brotzeni (Sigal), Sample 585-32-4, 97-99 cm, umbilical view. 10. Rotalipora greenhornensis (Morrow), Sample 585-32-4, 97-99 cm, umbilical view. 11-13. Rotalipora cushmani (Morrow), Sample 585-32-4, 97-99 cm, (11) spiral view, (12) side view, (13) umbilical view. 


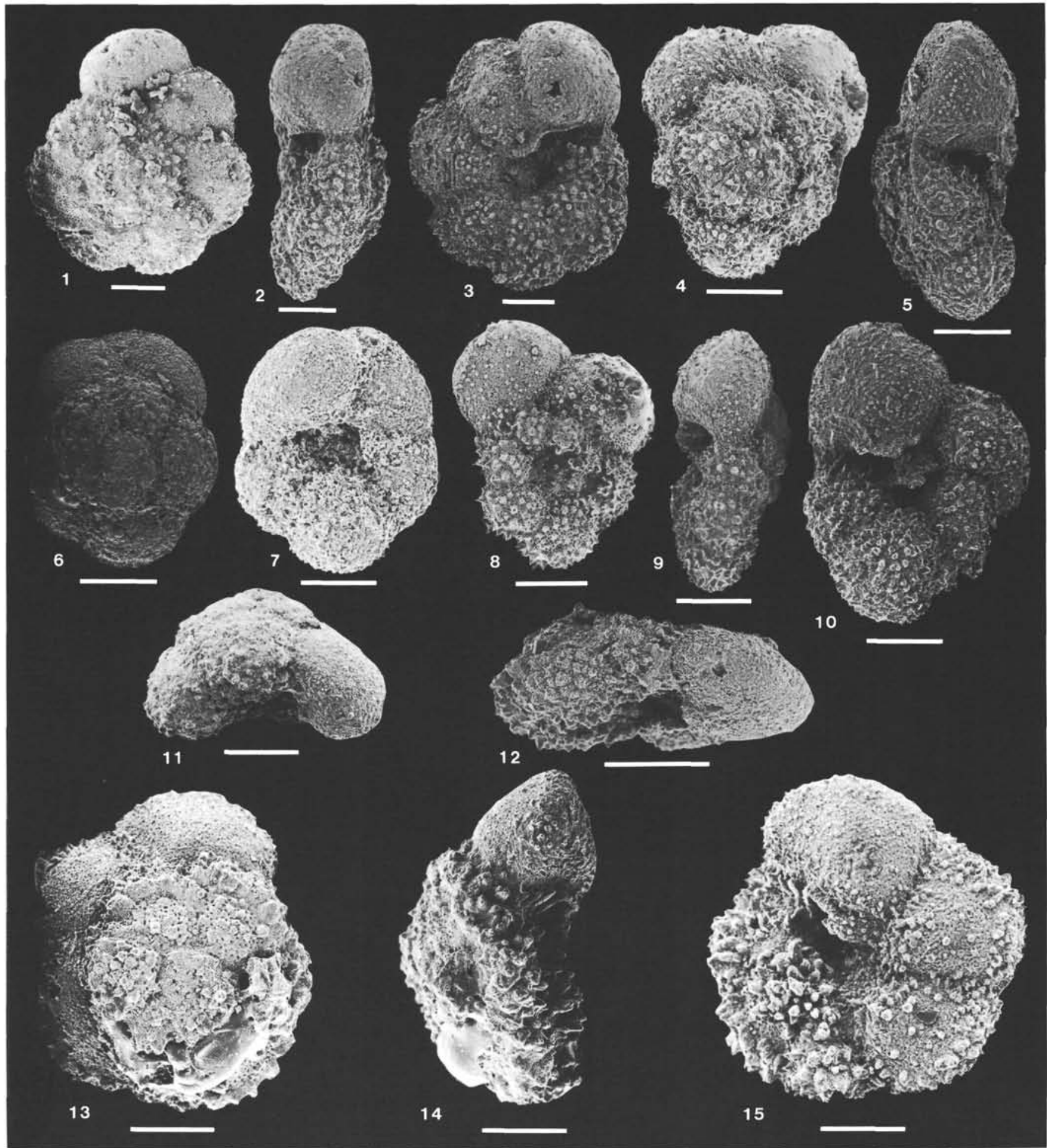

Plate 4. Scale bar $=100 \mu \mathrm{m}$. 1-3. Praeglobotruncana stephani (Gandolfi), Sample 585-32-4, 97-99 cm, (1) spiral view, (2) side view, (3), umbilical view. 4-5, 10. Praeglobotruncana aumalensis (Sigal), Sample 585-32-4, 97-99 cm, (4) spiral view, (5) side view, (10) umbilical view. 6-7, 11. Praeglobotruncana gibba Klaus, Sample 585A-9-1, 32-34 cm, (6) spiral view, (7) umbilical view, (11) side view. 8-9. Praeglobotruncana aumalensis (Sigal), Sample 585-32-4, 97-99 cm, (8) spiral view, (9) side view. 12. Praeglobotruncana stephani (Gandolfi), Sample 585-32-3, 24$27 \mathrm{~cm}$, side view. 13-15. Praeglobotruncana gibba Klaus, Sample 585A-9-1, 32-24 cm, (13) spiral view, (14) side view, (15) umbilical view. 


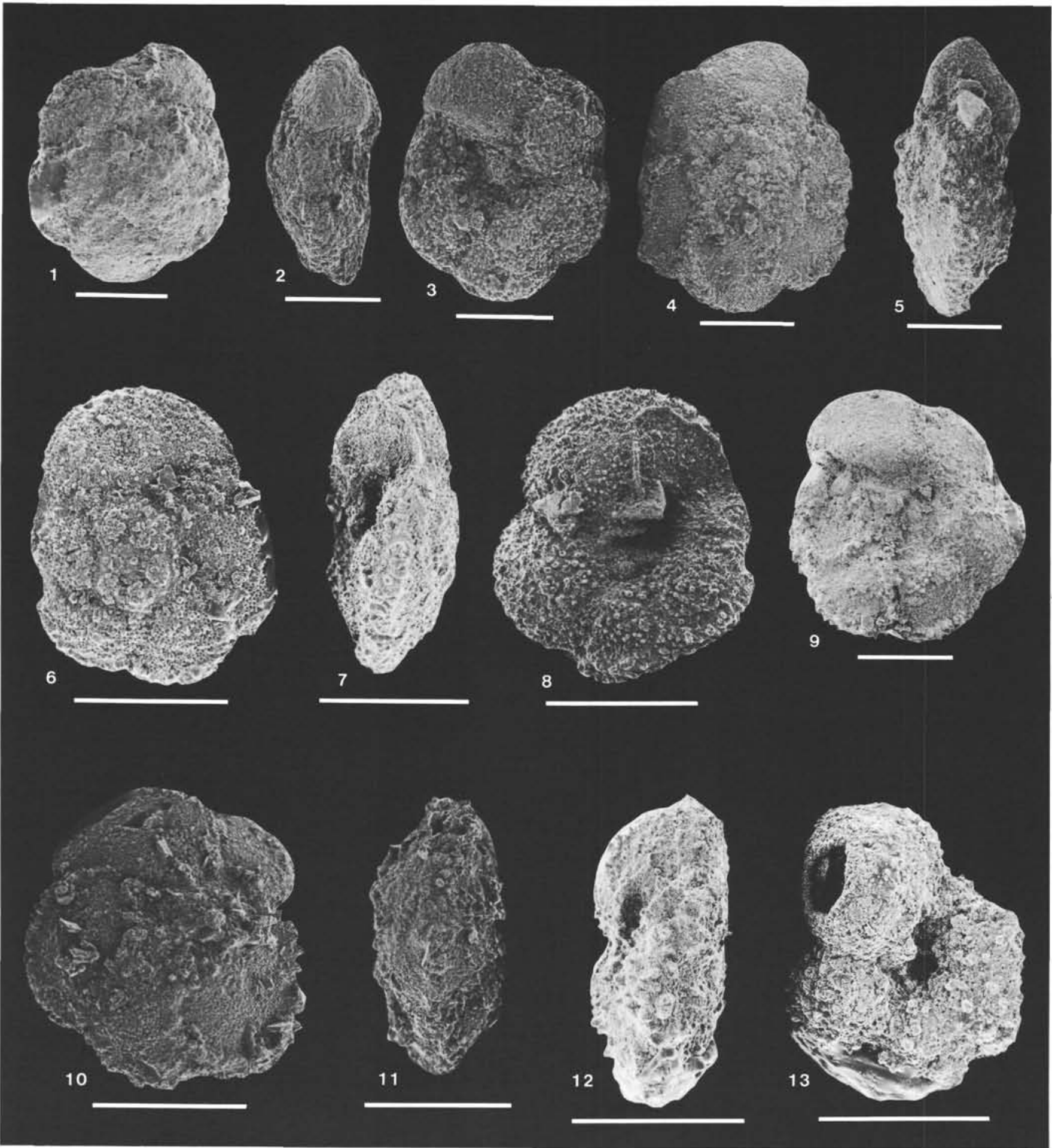

Plate 5. Scale bar $=200 \mu \mathrm{m}$. 1-3. Dicarinella sp. cf. D. hagni (Scheibnerova), Sample 585A-9-1, 4-7 cm, (1) spiral view, (2) side view, (3) umbilical view. 4-5, 9. Dicarinella hagni (Scheibnerova), Sample 585A-9-1, 4-7 cm, (4) spiral view, (5) side view, (9) umbilical view. 6-8. Dicarinella algeriana (Caron), Sample 585-32-4, 97-99 cm, (6) spiral view, (7) side view, (8) umbilical view. 10-11. Dicarinella hagni (Scheibnerova), Sample 585-32-4, 97-99 cm, (10) spiral view, (11) side view. 12-13. Dicarinella sp., Sample 585A-9-1, 4-7 cm, (12) side view, (13) umbilical view. 


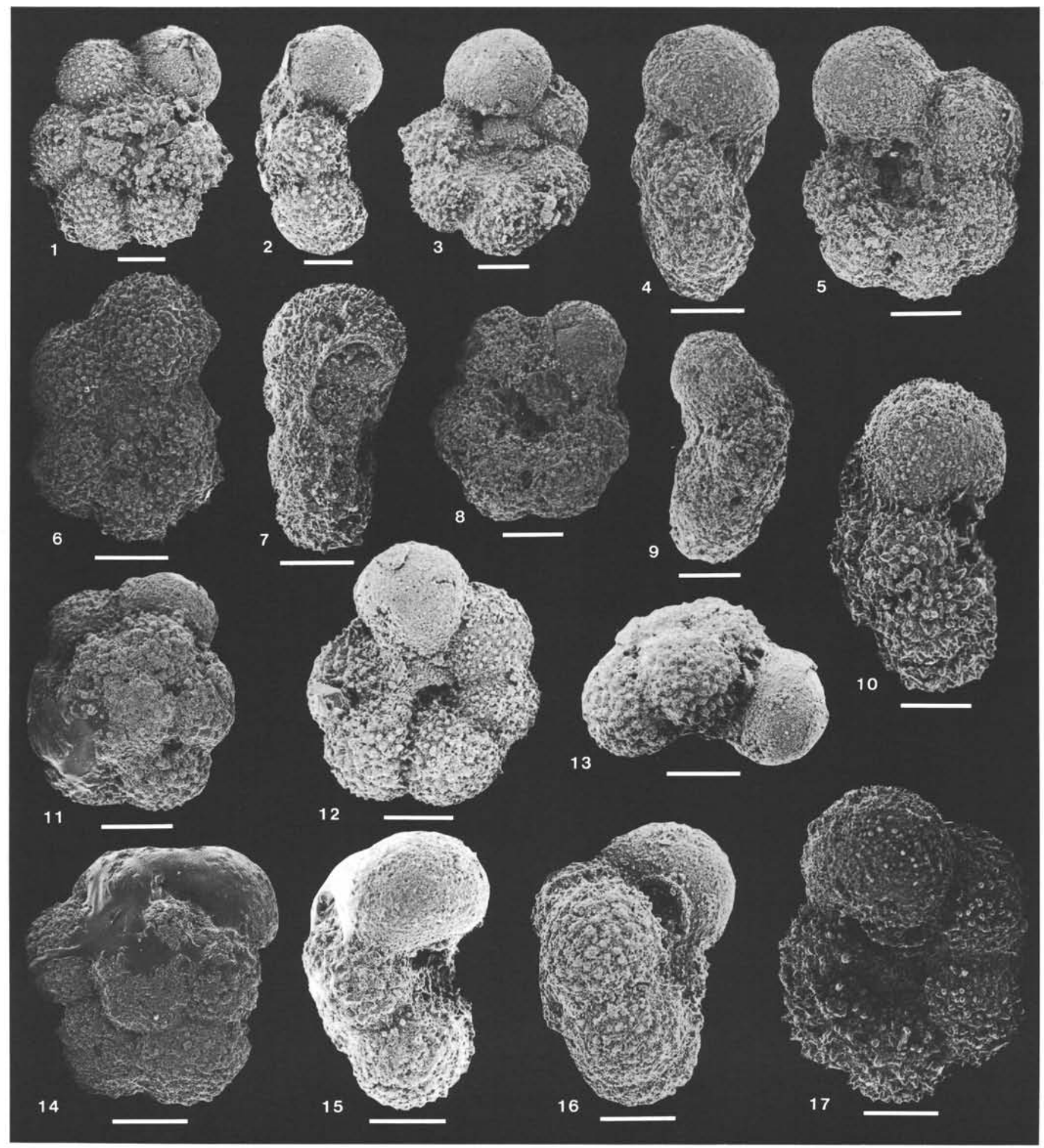

Plate 6. Scale bar $=100 \mu \mathrm{m}$. 1-3. Whiteinella aprica (Loeblich and Tappan), Sample 585-32-4, 97-99 cm, (1) spiral view, (2) side view, (3) umbilical view. 4-5. Whiteinella aprica (Loeblich and Tappan), Sample 585A-9-1, 4-7 cm, (4) side view, (5) umbilical view. 6-7. Whiteinella sp. aff. W. archaeocretacea Pessagno, 585A-9-1, 4-7 cm, (6) spiral view, (7) side view. 8-9. Whiteinella sp. aff. W. archaeocretacea Pessagno, Sample 585A-9-1, 64-72 cm, (8) umbilical view, (9) side view. 11-13. Whiteinella brittonensis (Loeblich and Tappan), Sample 585A-9-1, 32-34 cm, (11) spiral view, (12) umbilical view, (13) side view. 10, 17. Whiteinella aprica (Loeblich and Tappan), Sample 585-32-4, 97-99 cm, (10) side view, (17) umbilical view. 14-16. Whiteinella brittonensis (Loeblich and Tappan), Sample 585A-9-1, 32-34 cm, (14) spiral view, (15) side view, (16) oblique side view. 


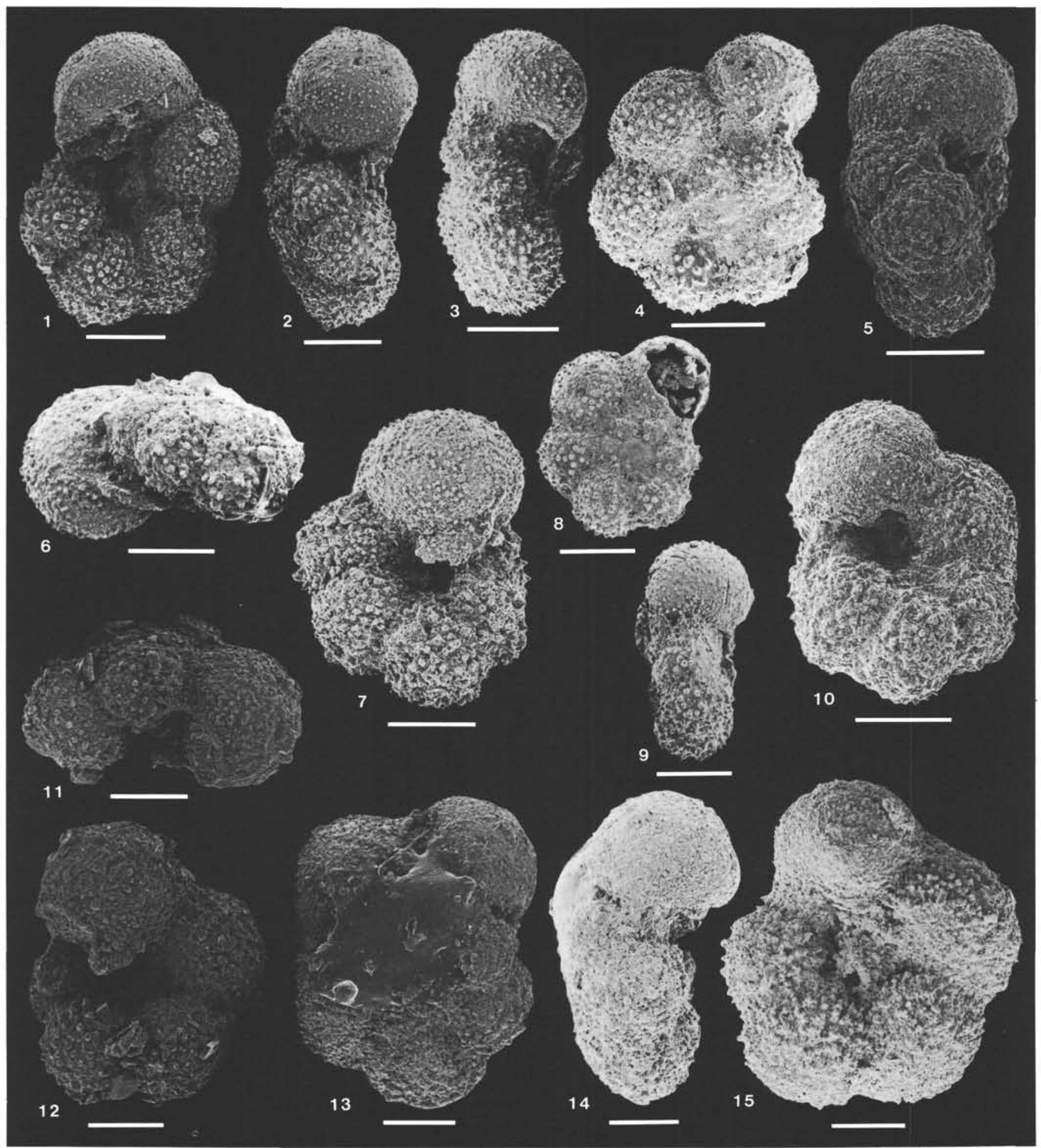

Plate 7. Scale bar $=100 \mu \mathrm{m}$. 1-2. Whiteinella sp. cf. $W$. archaeocretacea Pessagno, Sample 585-32-4, 97-99 cm, (1) umbilical view, (2) side view. 3-4. Whiteinella sp., Sample 585-32-3, 24-27 cm, (3) side view, (4) spiral view. 5, 10. Whiteinella baltica Douglas and Rankin, Sample 585A-9-1, 4-7 cm, (5) side view, (10) umbilical view. 6-7. Whiteinella baltica Douglas and Rankin, Sample 585A-9-1, 32-34 cm, (6) side view, (7) umbilical view. 8-9. Whiteinella sp., Sample $585-32-3,24-27 \mathrm{~cm},(8)$ spiral view, (9) side view. 11-12. Whiteinella baltica Douglas and Rankin, Sample 585-32-3, 24-27 cm, (11) side view, (12) umbilical view. 13-15. Whiteinella baltica Douglas and Rankin, Sample 585A-9-1, 32$34 \mathrm{~cm}$, (13) spiral view, (14) side view, (15) umbilical view. 


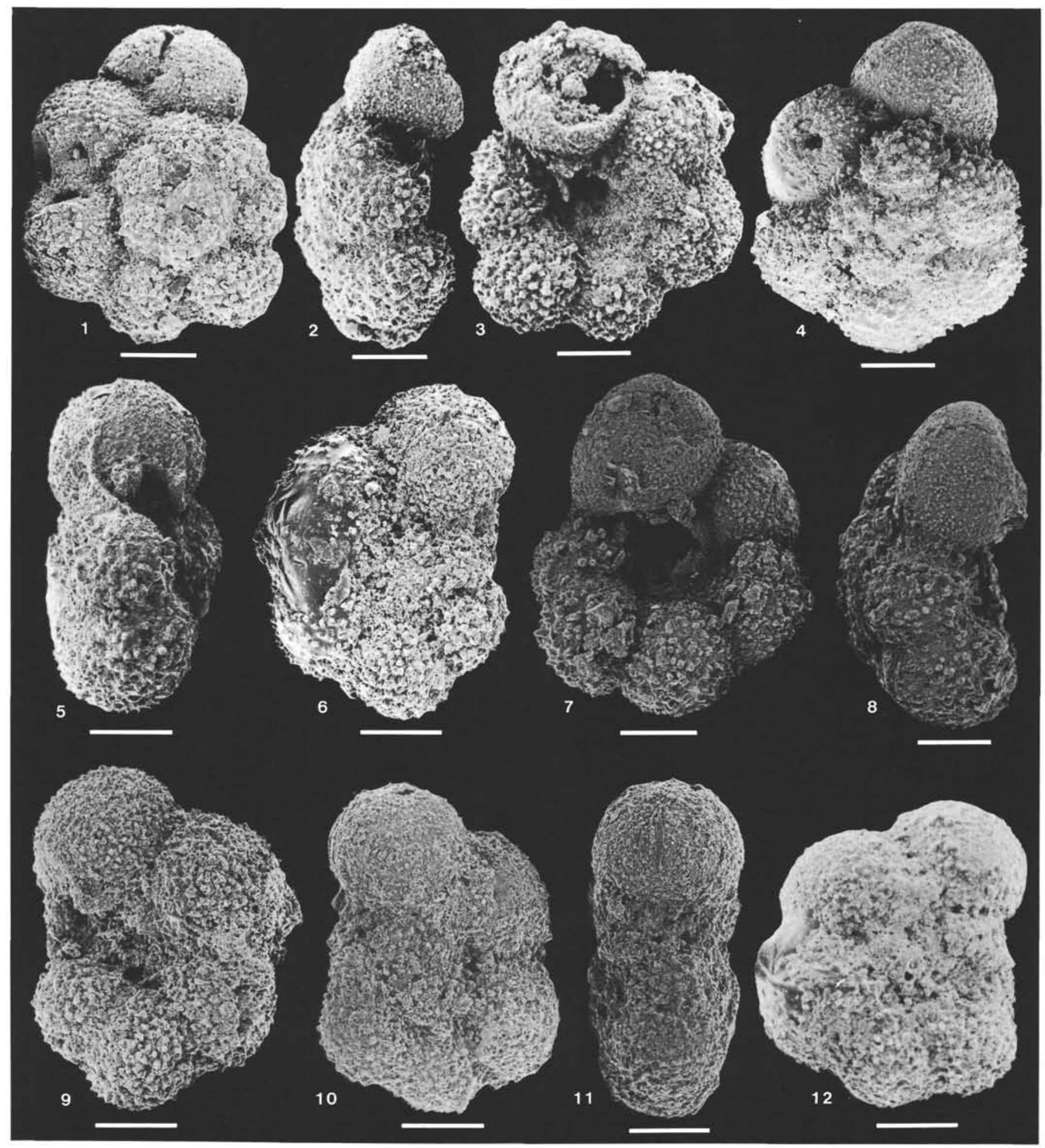

Plate 8. Scale bar $=100 \mu \mathrm{m}$. 1-3. Whiteinella sp. aff. W. aprica (Loeblich and Tappan), Sample 585-32-4, 97-99 cm, (1) sprial view, (2) side view,

(3) umbilical view. 4, 7-8. Whiteinella sp. aff. W. aprica (Loeblich and Tappan), Sample 585-32-4, 97-99 cm, (4) spiral view, (7) umbilical view, (8) side view. 5-6, 9. Whiteinella sp. cf. W. archaeocretacea Pessagno, Sample 585A-9-1, 32-34 cm, (5) side view, (6) spiral view, (9) umbilical view. 10-12. Whiteinella sp. cf. W. archaeocretacea Pessagno, Sample 585A-9-1, 4-7 cm, (10) spiral view, (11) side view, (12) umbilical view. 




Plate 9. Scale bar $=100 \mu \mathrm{m}$. 1-3. Whiteinella sp., Sample 585A-9-1, 32-34 cm, (1) spiral view, (2) umbilical view, (3) side view. 4-5. Dicarinella algeriana (Caron), Sample 585-32-4, 97-99 cm, (4) umbilical view, (5) side view. 6-8. Hedbergella delrioensis (Casey), Sample 585-32-3, 24-27 $\mathrm{cm}$, (6) spiral view, (7) side view, (8) umbilical view. 9, 12. Hedbergella? sp. Sample 585A-9-1, 4-7 cm, (9) umbilical view, (12) side view. 1011, 13. Praeglobotruncana stephani (Gandolfi), Sample 585-32-4, 97-99 cm, (10) side view, (11) spiral view, (13) umbilical view. 14-16. Marginotruncana? sp., Sample 585-32-4, 97-99 cm, (14) sprial view, (15) side view, (16) umbilical view. 